\title{
Late Quaternary Vegetation History of Sulphur Lake, Southwest Yukon Territory, Canada
}

\author{
T. LACOURSE ${ }^{1,2}$ and K. GAJEWSKI ${ }^{1}$
}

(Received 9 November 1998; accepted in revised form 9 June 1999)

\begin{abstract}
Paleoecological studies based on the analysis of pollen in lake sediments offer the potential for high resolution and well-dated independent records of past vegetation and climate. A $5 \mathrm{~m}$ sediment core was raised from the deepest section of Sulphur Lake, located in the southwest Yukon $\left(60^{\circ} 95 \mathrm{~N}, 137^{\circ} 95^{\prime} \mathrm{W} ; 847 \mathrm{~m}\right.$ a.s.l.). The pollen spectra indicate that before $11250 \mathrm{yr} \mathrm{BP}$, the vegetation was a herbaceous tundra marked by the presence of Artemisia. However, the date of the establishment of this initial vegetation cannot be secured because of problems with the basal radiocarbon date and the lack of a reliable chronology of regional deglaciation. A birch shrub tundra prevailed between 11250 and $10250 \mathrm{yr}$ BP and was then replaced by a discontinuous poplar woodland. Juniperus populations expanded at $9500 \mathrm{yr}$ BP, and by $8400 \mathrm{yr} \mathrm{BP}$, Picea invaded the region. The white spruce forest that occupies the region today was established by approximately $8000 \mathrm{yr}$ BP. Alnus crispa increased at $6000 \mathrm{yr}$ BP, but the simultaneous increase in Picea mariana found at most sites in the Yukon was not present at Sulphur Lake. Black spruce was never a dominant component of the vegetation in the southwest Yukon, as it was in the south-central Yukon between 6100 and 4100 yr BP.
\end{abstract}

Key words: pollen analysis, Quaternary paleoecology, southwest Yukon, spruce migration, vegetation history

RÉSUMÉ. Les études paléoécologiques fondées sur l'analyse de pollens de sédiments lacustres offrent la possibilité d'obtenir une chronologie de la paléovégétation et du paléoclimat à haute résolution et avec une datation précise. Une carotte de sédiment de $5 \mathrm{~m}$ a été prélevée dans la section la plus profonde de Sulphur Lake, situé au sud-ouest du Yukon (60 $95^{\prime} \mathrm{N}$., $137^{\circ} 95^{\prime} 0$.; $847 \mathrm{~m}$ alt.). D'après les spectres polliniques, la végétation a été une toundra herbacée marquée par la présence d'Artemisia avant 11250 ans B.P. Cependant, la date de colonisation de cette végétation ne peut être déterminée de façon définitive à cause des problèmes de datation du début de la séquence sédimentologique et l'absence d'une chronologie fiable de la déglaciation régionale. Une toundra arbustive à bouleau a prédominé entre 11250 B.P. et 10250 B.P., et a ensuite été remplacée par une région boisée de peuplier discontinu. Les populations de Juniperus ont augmenté vers 9500 ans B.P. et, vers 8400 ans B.P., Picea a colonisé la région. La forêt relativement fermée d'épinettes blanches qui occupe la région aujourd'hui s'est établie vers 8000 ans B.P. Alnus crispa s'est répandu il y a environ 6000 ans B.P. Alors qu'on retrouve une augmentation de Picea mariana à cette époque dans la plupart des sites dans le Territoire du Yukon, celle-ci n'a pas eu lieu à Sulphur Lake. L'épinette noire n'a jamais été une composante dominante de la végétation au sud-ouest du Yukon comme elle l'a été entre 6100 et 4100 ans B.P. au centre-sud du Yukon.

Mots clés: analyses polliniques, paléoécologie quaternaire, sud-ouest du Yukon, migration de l'épinette, histoire de la végétation

\section{INTRODUCTION}

The southwest Yukon is a region that warrants detailed biogeographical and paleoenvironmental investigation. Many species characteristic of the North American boreal forest, including black spruce (Picea mariana), larch (Larix laricina), and paper birch (Betula papyrifera), are rare or absent in the southwest Yukon. Yet, with a large number of disjunct species and species endemic to Alaska and the Yukon (Stellaria alaskana, Salix setchelliana, Androsace alaskana, Castilleja yukonis, Artemisia alaskana, Aster yukonensis, and Claytonia bostockii) (Murray and Douglas, 1980), substantial ecological diversity remains.
Because of its high elevation and proximity to alpine glaciers, the southwest Yukon displays steep environmental gradients. Cold, dry arctic air masses influence the area, while the warm, moist Pacific air masses are modified in transit over the St. Elias Mountains. Lying at the boundary between these two major climate systems, the southwest Yukon is sensitive to even minor environmental changes.

Although a number of paleoecological studies have been undertaken in the southwest Yukon, unresolved questions remain. The direction of spruce migration in this region is still not fully understood. Cwynar $(1982,1988)$ and MacDonald (1984) suggested that spruce migrated from the upper Liard River to the Yukon River drainage

\footnotetext{
${ }^{1}$ Department of Geography, University of Ottawa, Ottawa, Ontario K1N 6N5, Canada

${ }^{2}$ Present address: Department of Biological Sciences, Simon Fraser University, 8888 University Drive, Burnaby, British Columbia V5A 1S6, Canada; terri_lacourse@sfu.ca

(C) The Arctic Institute of North America
} 
system into the southwest Yukon, but both cautioned that more sites are required before a precise migration route can be determined. A second question concerns the early suggestion that extensive grasslands were present in the southwest Yukon for much of the Holocene (Johnson and Raup, 1964; Workman, 1978; Morlan and Workman, 1980). Cwynar (1988), Stuart et al. (1989), Wang and Geurts (1991b), and Keenan and Cwynar (1992) found no evidence in their study areas to support this suggestion, but more data are needed for a complete rejection of this hypothesis. Widespread increases in black spruce (Picea mariana) and green alder (Alnus crispa) occurred throughout most of the Yukon between 6500 and $6000 \mathrm{yr}$ BP (Cwynar and Spear, 1995). These vegetational changes are less clear in the southwest Yukon and thus require further investigation.

These questions can be addressed with well-dated reconstructions of postglacial vegetation history in the southwest Yukon Territory. To this end, a paleoecological study at Sulphur Lake in the Kluane Lake region (Fig. 1) was conducted to further define the vegetation history of this region.

\section{STUDY AREA}

The modern vegetation of the southwest Yukon has been well studied (Johnson and Raup, 1964; Price, 1971; Rowe, 1972; Douglas, 1974; Hoefs et al., 1975; Birks, 1977; Oswald and Senyk, 1977; Orlóci and Stanek, 1979; Murray and Douglas, 1980; Parent, 1988). Closed-to-open boreal forests dominated by white spruce (Picea glauca) occupy valley bottoms. Black spruce ( $P$. mariana), larch (Larix laricina), and white birch (Betula papyifera) are uncommon or absent in the southwest Yukon. Extensive stands of poplar (Populus tremuloides and P. balsamifera) are common, especially on warmer sites. Shrub willow (Salix glauca), dwarf birch (Betula glandulosa), and, to a lesser extent, Shepherdia canadensis are important constituents of the regional vegetation, while alder (Alnus spp.) is scarce, present only as scattered shrubs (Johnson and Raup, 1964). Lodgepole pine (Pinus contorta) and subalpine fir (Abies lasiocarpa) are absent from the region but become increasingly important to the east and south. Artemisia-dominated communities occur on dry, southfacing slopes, particularly surrounding Kluane Lake and in Kluane National Park. In the Shakwak Trench, the treeline varies between 1066 and $1220 \mathrm{~m}$ (Johnson and Raup, 1964), with alpine tundra at higher elevations.

Sulphur Lake $\left(60^{\circ} 95^{\prime} \mathrm{N}, 137^{\circ} 9^{\prime} \mathrm{W}\right.$; $847 \mathrm{~m}$ a.s.l.) is located in the Shakwak Trench adjacent to the Alaska Highway, approximately $26 \mathrm{~km}$ southeast of Kluane Lake (Fig. $1)$. It is a large lake ( 150 ha) with two main basins, a shallow $(2 \mathrm{~m})$ southwest basin and a much deeper $(10 \mathrm{~m})$ northeast basin, which are separated to some extent by a point that extends into the center of the lake (Fig. 2). Sulphur Lake is characterized by magnesium-rich

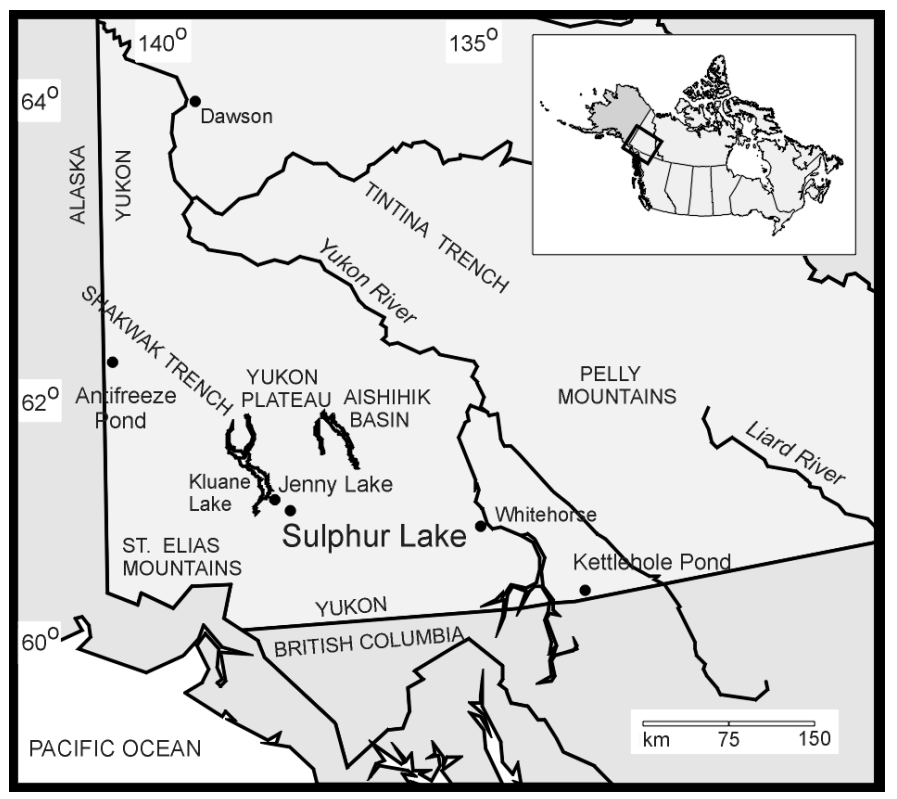

FIG. 1. Map of the southwest Yukon Territory, showing Sulphur Lake and other localities mentioned in the text.

bicarbonate waters, with low nutrient $(0.1 \mu \mathrm{g} / \mathrm{L}$ TPU $)$ and chlorophyll $a(0.62 \mu \mathrm{g} / \mathrm{L})$ levels.

\section{METHODS}

Three duplicate sediment cores, $5 \mathrm{~cm}$ in diameter, were recovered from the deepest basin of Sulphur Lake (Fig. 2) using a modified Livingstone piston sampler (Wright, 1967) operated from a raft anchored at three points. PVC casing was used to direct the corer. Lake bathymetry was determined through sonar measurements. Cores were extruded in the field and wrapped in plastic and aluminium foil to maintain the integrity of each core during transport. The uppermost unconsolidated sediment was extruded at 1 $\mathrm{cm}$ intervals using a portable extruding device (Glew, 1988). Whole core X-radiography and magnetic susceptibility served as nondestructive methods for correlating core segments and determining the depth of the White River Ash. Whole core magnetic susceptibility was measured at $1 \mathrm{~cm}$ intervals using a Bartington MS2C Core sensor (6 $\mathrm{cm}$ internal diameter).

A calibrated brass sampler was used to remove $1 \mathrm{cc}$ subsamples at $5 \mathrm{~cm}$ intervals for pollen analysis. Preacetolyzed Lycopodium spores in tablet form were added to each subsample to determine pollen concentrations and accumulation rates (Benninghoff, 1962). Standard methods for pollen analysis were followed (Cwynar et al., 1979; Faegri and Iversen, 1989). A minimum sum of 500 grains was counted for each subsample. The differentiation of Picea glauca and P. mariana pollen grains was based upon morphological characteristics outlined by Hansen and Engstrom (1985). All undifferentiated Picea grains (an average of $10 \%$ of the grains) were assigned to either $P$. glauca or $P$. mariana according to the proportional 


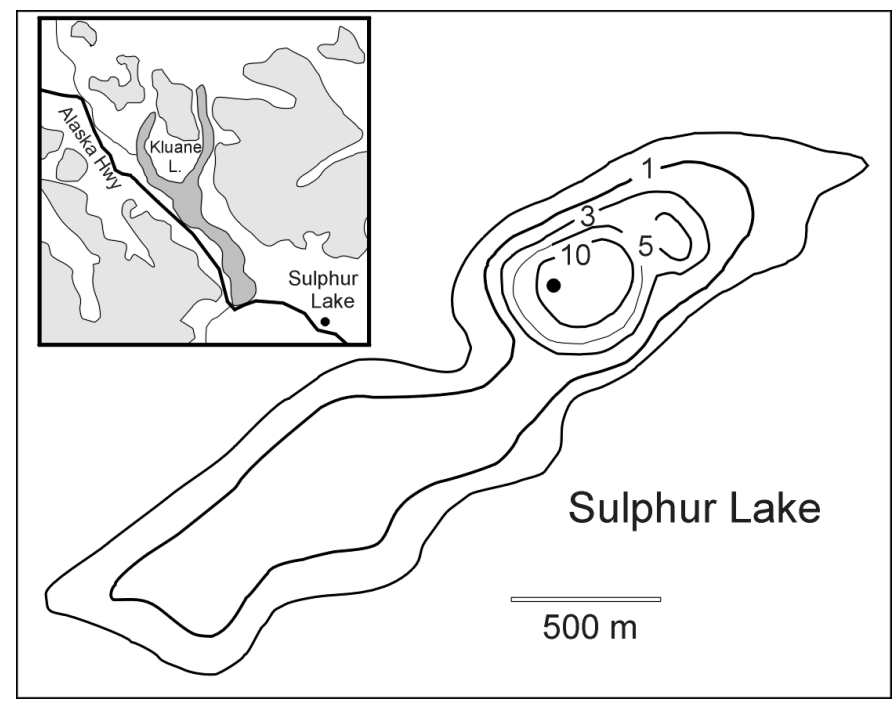

FIG. 2. Bathymetric map of Sulphur Lake showing the coring location (ø). Light shading in the inset map indicates elevation over $1525 \mathrm{~m}$.

TABLE 1. Radiocarbon dates from Sulphur Lake, southwest Yukon Territory, Canada.

\begin{tabular}{|c|c|c|c|}
\hline Laboratory No. & $\begin{array}{c}\text { Depth of } \\
\text { sample }(\mathrm{cm})\end{array}$ & $\begin{array}{l}\text { Radiocarbon age } \\
\quad(\mathrm{BP} \pm 1 \mathrm{SD})\end{array}$ & Material \\
\hline BETA-104734 & $87.5-89.5$ & $1960 \pm 50$ & bulk sediment \\
\hline BETA-109436 & $131.0-132.5$ & $2700 \pm 70$ & $\begin{array}{l}\text { Picea seed and } \\
\text { Cyperaceae leaves }\end{array}$ \\
\hline BETA-109437 & $320.3-321.7$ & $6240 \pm 50$ & shrub branch \\
\hline BETA-109438 & $368.0-370.0$ & $8240 \pm 50$ & $\begin{array}{l}\text { Picea } \text { seed and } \\
\text { Drepanocladus sp. }\end{array}$ \\
\hline BETA-104735 & $410.5-412.5$ & $9530 \pm 60$ & bulk sediment \\
\hline BETA-104736 & $454.0-457.0$ & $10820 \pm 90$ & bulk sediment \\
\hline BETA-104737 & $496.0-499.0$ & $17370 \pm 140$ & bulk sediment \\
\hline
\end{tabular}

distribution of the grains identified to species. Alnus crispa and $A$. rugosa were discriminated on the basis of morphological criteria described by Richard (1970). Plant macrofossils were recovered from the core and were identified where possible. Four bulk sediment samples and three plant macrofossils were submitted to Beta Analytic Radiocarbon Dating Laboratory for accelerator mass spectrometer (AMS) ${ }^{14} \mathrm{C}$ dating. Sediment cores were subsampled to estimate the portion of inorganic and organic materials through loss on ignition (Dean, 1974), and carbonate content was estimated by removing carbonate with $10 \% \mathrm{HCl}$.

\section{RESULTS}

\section{Sediment Stratigraphy}

A $5 \mathrm{~m}$ long sediment core from Sulphur Lake was analysed for the purpose of reconstructing the vegetation history. The uppermost $315 \mathrm{~cm}$ consist of homogeneous brown gyttja. The White River Ash (WRA) (Lerbekmo et al., 1975; Clague et al., 1995), identified based on geographic
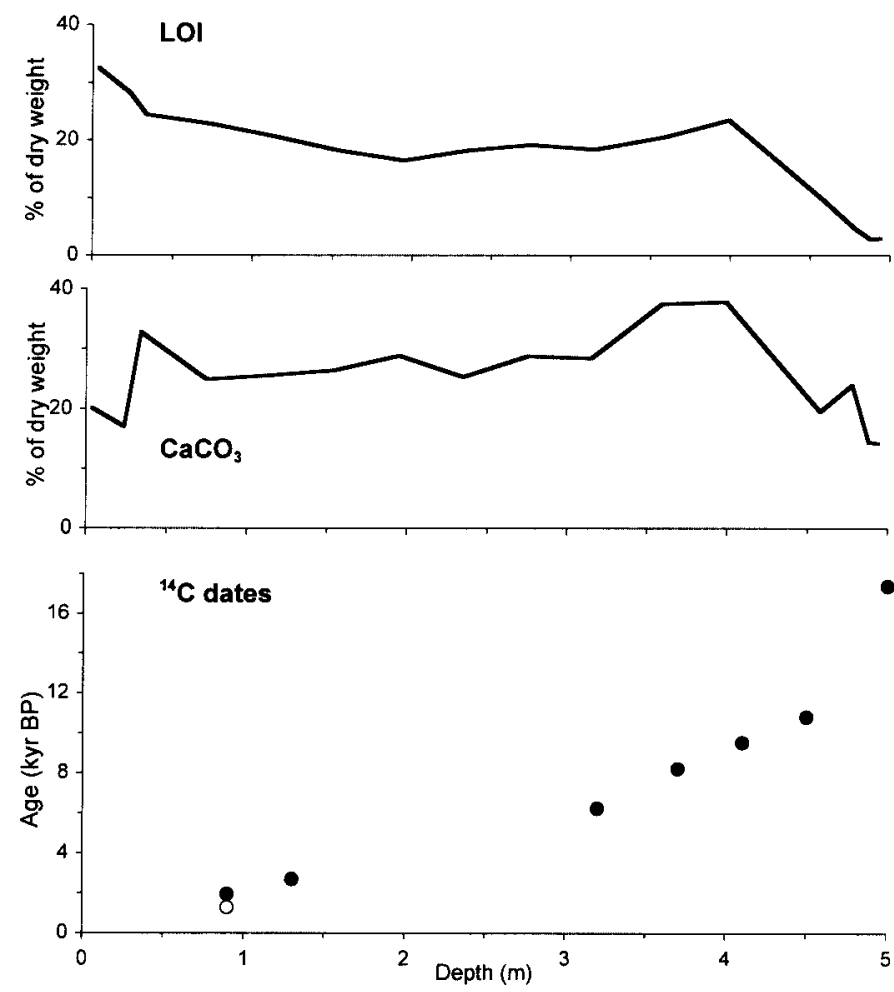

FIG. 3. Sulphur Lake radiocarbon dates, carbonate content $\left(\mathrm{CaCO}_{3}\right)$, and loss on ignition (LOI) versus sediment depth. The open circle represents the Clague et al. (1995) date of the White River Ash.

location, $\mathrm{x}$-radiography, magnetic susceptibility and visual inspection, lies $88 \mathrm{~cm}$ below the water-sediment interface. Between 315 and $415 \mathrm{~cm}$, the sediment is blackish brown silty gyttja intermittently laminated with fine-grained layers that are lighter in colour. The basal sediments, from 415 to $500 \mathrm{~cm}$, are dark grey to black fine-grained sediments; their magnetic susceptibility increases with depth, indicating an increase in grain size and inorganic content towards the base of the sequence (Thompson et al., 1980).

\section{Chronology}

The seven radiocarbon dates (Table 1, Fig. 3) are in chronological order, irrespective of the type of material that was dated. There is a hard-water effect, as shown by our bulk sediment date of $1960 \pm 50 \mathrm{yr}$ BP for sediment at the position of the White River Ash (BETA-104734). On the basis of four dates, Clague et al. (1995) assigned a weighted mean of $1147 \mathrm{cal} \mathrm{yr} \mathrm{BP}(1300 \pm 90 \mathrm{yr} \mathrm{BP})$ to the tephra. This suggests a hard-water error of 660 radiocarbon years for this portion of the core. When only the White River Ash and the one date (BETA-109437) based entirely on a terrestrial sample are used, the remaining dates all fall above a linear fit line, and the deviation from that line increases with depth. With only one estimate of the hardwater effect, the remaining radiocarbon dates were not adjusted, since it was not feasible to determine whether the offset was linear for the period of record. Therefore, the 


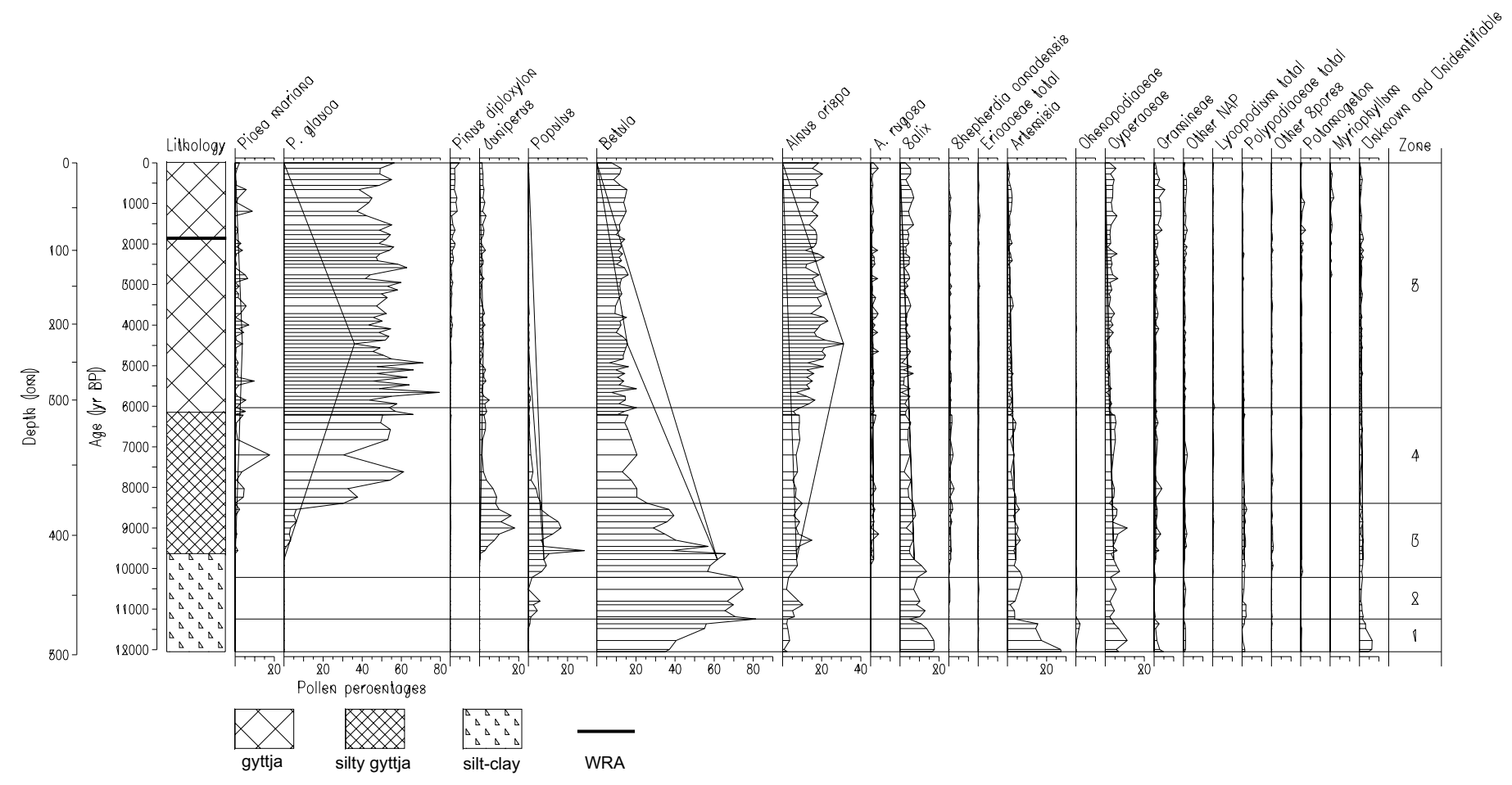

FIG. 4. Summary pollen percentage diagram from Sulphur Lake, Yukon Territory. White River Ash (WRA) lies at a depth of $88 \mathrm{~cm}$.

uncorrected chronology was used. The potential offset was considered in the interpretation of the palynological record. Individual pollen spectra were dated through linear interpolation between radiocarbon dates.

The basal date of $17370 \mathrm{yr}$ BP (BETA-104737) appears to be too old, given the accepted date of $12500 \mathrm{yr}$ BP for clearance of ice from the Shakwak Trench (Denton and Stuiver, 1966, 1967). The accepted date was based on bulk sediment from nearby Jenny Lake (Fig. 1) that has a 70$80 \%$ carbonate content in basal sediments (P. Johnson, pers. comm. 1998). Bulk sediment dates are often problematic where carbonate content is high. The carbonate content of the basal sediments at Sulphur Lake is only $14 \%$ (Fig. 3), considerably lower than that of basal sediments at Jenny Lake. However, the loss on ignition indicates that the basal sediments of Sulphur Lake contain less than 5\% organic matter (Fig. 3). For this reason, the basal date of $17370 \mathrm{yr}$ BP is not used in establishing the Sulphur Lake chronology.

For the pollen diagram, levels below $10820 \mathrm{yr}$ BP (BETA-104736) were dated through linear extrapolation, using the sedimentation rate of the section from 411.5 to $455.5 \mathrm{~cm}$. This dating puts the base of the sequence at roughly $12000 \mathrm{yr}$ BP. This method was chosen because the upper six dates are all well aligned. The chronology of the basal sediments may need to be revised using the basal date of $17370 \mathrm{yr}$ BP if deglaciation was earlier than 12500 yr BP. However, the high carbonate content of Jenny Lake basal sediments suggests that even Denton and Stuiver's (1966) date of $12500 \mathrm{yr}$ BP for clearance of ice from the Shakwak Trench may be too old. Perhaps the chronology of deglaciation, and more specifically the clearance of ice from the Shakwak Trench, needs to be more firmly dated.

\section{Palynological Record}

The Sulphur Lake pollen percentage diagram (Fig. 4) is divided into 5 zones.

Zone 1 (Betula - Artemisia - Salix, >11 250 yr BP; 470$500 \mathrm{~cm}$ ): This zone is dominated by high percentages of Betula (35-81\%), Artemisia (4-27\%), Salix (5-18\%), and Cyperaceae (3-11\%). Artemisia, Salix, Chenopodiaceae and Cyperaceae reach their maximum for the period of record in this zone.

Zone 2 (Betula, 11250-10250 yr BP; $470-435 \mathrm{~cm}$ ): Betula reaches its maximum ( $81 \%$ ) for the period of record in this zone. Salix is relatively abundant $(5-13 \%)$. Populus pollen is present in this zone but remains less than $6 \%$ of the pollen sum. Alnus crispa rises in this zone, and total herb pollen decreases.

Zone 3 (Populus - Juniperus, 10 250-8400 yr BP; 435 $374 \mathrm{~cm})$ : This zone is marked by a significant decline in Betula (26-66\%) and an increase in Populus (6-29\%). Juniperus arrives by $9500 \mathrm{yr} \mathrm{BP}$ and accounts for up to $18 \%$ of the pollen sum. Picea pollen is present in small amounts.

Zone 4 (Picea glauca, 8400-6000 yr BP; 374-310 cm): Zone 4 is characterized by the arrival of Picea, the majority of which is $P$. glauca. Picea glauca rises from $6 \%$ to $60 \%$ in a period of roughly 900 years. Betula remains more or less constant until the present. Juniperus and Populus pollen both decline to trace amounts. Alnus crispa, Salix, 


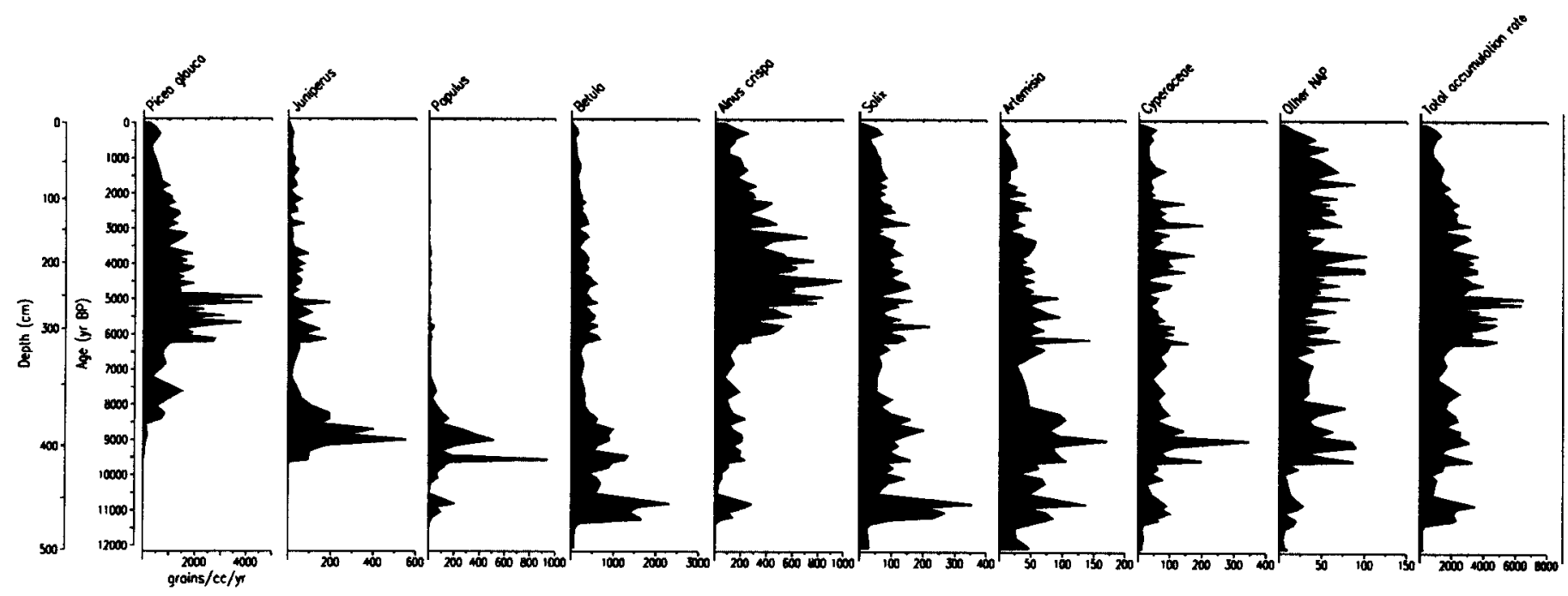

FIG. 5. Pollen accumulation rates for selected taxa from Sulphur Lake, Yukon Territory. Note changes in scale.

Artemisia and Cyperaceae remain constant at low levels.

Zone 5 (Picea glauca - Alnus, 6000 yr BP to present; $310 \mathrm{~cm}$ to surface): Picea glauca remains at high levels throughout this zone, with some variability including a marked decrease between roughly 1250 and $600 \mathrm{yr}$ BP. Alnus crispa increases gradually from 6000 to $4500 \mathrm{yr} \mathrm{BP}$, reaching values up to $30 \%$. Pinus pollen is continuously present by $5000 \mathrm{yr}$ BP and increases shortly after the deposition of the White River Ash. Gramineae, Salix, Betula and aquatic pollen (Potamogeton and Myriophyllum) increase around $1500 \mathrm{yr}$ BP.

Total pollen accumulation rates (PARs) increase from the base of the record to a maximum between 5000 and $6000 \mathrm{yr}$ BP (Fig. 5). This maximum is largely due to the increase in Picea glauca PARs at this time and corresponds to the maximum of Picea glauca and Alnus crispa in the pollen percentage diagram (Fig. 4). Cyperaceae, Salix and Artemisia PARs as well as other herb PARs are low in the basal sediments, whereas in the pollen percentage diagram (Fig. 4) these types are at a maximum. Salix PARs reach their maximum later during the birch shrub tundra stage, and maximum nonarboreal pollen (NAP) PARs occur around $9000 \mathrm{yr}$ BP, during the PopulusJuniperus zone (Fig. 5). In the late Holocene, Picea glauca, Alnus crispa, and total PARs gradually decrease until the present. This decline in PARs may reflect reduced compaction or decreased sediment focusing or both. However, it may also reflect lower pollen production related to cooler climates.

\section{DISCUSSION}

Immediately following deglaciation, the pollen assemblages were dominated primarily by Betula, Artemisia, Salix, and Cyperaceae. This basal zone represents a shrub birch-herb tundra marked by relatively low amounts of Betula, high NAP (including Chenopodiaceae, Asteraceae, and Rumex) and an abundance of Artemisia. Climate during this time was drier and colder than at present. Total pollen accumulation rates are low at this time (Fig. 5), suggesting that the vegetation was an open, tundra environment (Davis et al., 1984; Delcourt and Delcourt, 1991). High inorganic content in basal sediments also suggests sparse vegetative cover as well as significant loess input. Today, Artemisia-dominated communities in the southwest Yukon grow primarily in open, dry habitats on warm, south-facing slopes (Johnson and Raup, 1964; Douglas, 1974). The modern influx of Artemisia pollen is considerably lower than that in late glacial sediments. Given the relatively high influx of Artemisia pollen following deglaciation, Artemisia communities must have been more extensive in the late glacial era than they are today. However, these are not comparable habitats. The presence of Betula, Salix, and other NAP in the late glacial indicate a sparse tundra community, whereas today in the southwest Yukon Artemisia spp. are found in localized grassforb communities. Hence, a sparse herbaceous tundra dominated by Artemisia probably occupied xeric upland sites, while birch and willow shrubs were common in lowlands.

By roughly $11250 \mathrm{yr} \mathrm{BP}$, this herbaceous tundra was replaced by a birch shrub tundra. Total PARs (Fig. 5) increased significantly with the establishment of a birch shrub tundra, indicating that a more continuous vegetative cover prevailed. This increase in Betula and total influx signals increased moisture and probably warmer summer temperatures. The first appearance of Populus coincides with the dominance of shrub birch at this time. Populus may have grown in some of the drier habitats. Alnus crispa began to rise slowly, but it is less than clear whether it was growing locally. Modern pollen assemblages indicate that Alnus is significantly overrepresented in the Shakwak Trench (Lacourse, 1998). Birks $(1977,1980)$ also documented the overrepresentation of Alnus pollen in the southwest Yukon.

By 10250 yr BP, Betula began to decline, perhaps because of a lower tolerance of arid conditions, and the birch shrub tundra was gradually replaced by a poplar woodland with an understory of shrub birch. Both trembling 
aspen (Populus tremuloides) and balsam poplar ( $P$. balsamifera) are abundant in the Kluane Lake region today, but only trace amounts of Populus pollen are found in modern surface samples (Lacourse, 1998). This underrepresentation of Populus in surface sediments suggests that the peak in Populus between 10250 and $8000 \mathrm{yr}$ $\mathrm{BP}$ represents the establishment of a significant poplar community in the southwest Yukon, as opposed to merely gallery forests along rivers. A peak in Populus around $10000 \mathrm{yr} \mathrm{BP}$ is a common feature of pollen diagrams from Alaska, Yukon Territory, and the adjacent Northwest Territories (Ritchie, 1984, 1987). In fact, this kind of zone is found in late glacial sediments throughout Canada (Mott, 1978).

Juniperus, the first conifer to colonize the area, arrived by $9500 \mathrm{yr}$ BP. Its presence indicates openings in the woodland vegetation and well-drained, unshaded habitats (Ritchie, 1984, 1987). It probably grew in woodland gaps as well as on dry, open slopes that previously had been occupied by Artemisia. The addition of juniper shrubs to the landscape around 9500 yr BP corresponds with a change in the sediment stratigraphy at $415 \mathrm{~cm}$ (Fig. 4), suggesting widespread changes in edaphic parameters at this time. A decrease in loess production resulting from a more continuous vegetative cover might explain the increase in organic content.

Trace amounts of Picea pollen were present by roughly $9500 \mathrm{yr} \mathrm{BP}$, and white spruce has dominated the landscape from $8400 \mathrm{yr}$ BP until the present. A spruce seed dated at $8240 \pm 50$ yr BP (BETA-109438) confirms its local presence. The combination of white spruce, poplar, shrub birch, willow, and juniper indicates that a boreal forest, similar in structure and composition to the boreal forest present in the southwest Yukon today, had been established by approximately $8000 \mathrm{yr}$ BP. This suggests an overall increase in effective moisture and temperature. Given the length of time required for spruce migration (Ritchie and MacDonald, 1986), it is probable that the arrival of spruce lagged behind the postglacial climatic change.

Too few sites have been studied in the southwest Yukon to draw concrete conclusions on the pattern of spruce migration. Cwynar (1982, 1988) and MacDonald (1984) proposed that spruce migrated from northern British Columbia through the upper Liard River to the Yukon River drainage system and then into the southern Yukon. Spruce arrived west of the Liard Plain at Kettlehole Pond at 9250 yr BP (Cwynar, 1988), and in the central Aishihik Basin by $8600 \mathrm{yr}$ BP (Wang, 1989). It is therefore conceivable that spruce migrated from northern British Columbia to the Liard River and then into the Tintina Trench to continue further north. However, spruce migrated up the Mackenzie Valley, arriving in the Mackenzie Delta before $9000 \mathrm{yr}$ BP (Ritchie, 1987). Wang and Geurts (1991a) suggested that spruce migrated southward from the Tintina Trench into the Aishihik Basin and its adjacent area via the Yukon River plain. In the central Yukon, just to the north of Dawson, there is clear macrofossil evidence of spruce at
9400 yr BP (Cwynar and Spear, 1991). There is also evidence of spruce in central Alaska by $9000 \mathrm{yr}$ BP (Anderson and Brubaker, 1993). Spruce had arrived at Antifreeze Pond on the Alaska-Yukon border at $8700 \mathrm{yr}$ BP (Rampton, 1971). From the Tintina Trench, spruce could have migrated south into the Kluane Lake region to arrive at Jenny Lake at $8500 \mathrm{yr}$ BP (Stuart et al., 1989) and at Sulphur Lake at 8400 yr BP. However, as both Cwynar (1988) and Wang and Geurts (1991a) noted, we need additional sites, particularly to the east in the Pelly Mountains and along the Yukon River plain, to secure the pattern of spruce migration into the southwestern Yukon.

Alnus crispa increased significantly at $6000 \mathrm{yr}$ BP, indicating cooler and moister conditions, as suggested by Cwynar and Spear (1995). Ritchie (1984) associates an increase in Alnus with increased paludification and permafrost development in the Northwest Territories. The increase in Picea glauca and Alnus crispa PARs (Fig. 5) at this time suggests that forest cover was more continuous. This change in vegetation and climate occurs simultaneously with a lithological change at Sulphur Lake (Fig. 4), which suggests that edaphic parameters that affected sediment deposition also changed at this time. For example, with moister conditions and increased forest cover, loess input to Sulphur Lake would have decreased (Nickling, 1978), explaining in part the transition from silty gyttja to homogenous brown gyttja at $315 \mathrm{~cm}$. Throughout the Yukon, the increase in Alnus crispa in the mid-Holocene is usually accompanied by an increase in Picea mariana (Cwynar and Spear, 1995). The history of Picea mariana is less clear in the Shakwak Trench (Cwynar, 1988). At Sulphur Lake, black spruce was never a significant component of the vegetation, as it was to the southeast at Kettlehole Pond (Cwynar, 1988). Conditions may have been too dry at Sulphur Lake to support black spruce. However, this is the first diagram from the Shakwak Trench to differentiate white and black spruce pollen; with additional sites, the importance of black spruce could be better determined. Stuart et al. (1989) interpret the rise in Alnus at nearby Jenny Lake at $4500 \mathrm{yr}$ BP to represent the establishment of a spruce-alder woodland. However, modern pollen assemblages indicate that Alnus is severely overrepresented in the southwest Yukon. Values of up to $30 \%$ were obtained at sites where alder was not growing locally (Lacourse, 1998). It is therefore possible that alder was not as important a constituent of the regional vegetation as the sequence suggests: rather, its pollen was merely transported long distances.

Only minor adjustments in the vegetation occurred following the rise in Alnus crispa at $6000 \mathrm{yr}$ BP. At approximately 1500 yr BP, Gramineae, Salix, Betula and total NAP increased at the expense of Picea glauca. In view of the 660 year difference between the accepted date of the White River Ash (Clague et al., 1995) and the date obtained from Sulphur Lake, the decrease in white spruce may correspond to the Little Ice Age, during which it is known that glaciers advanced in the St. Elias Mountains 
(Denton and Karlén, 1977). The increase in aquatics (Potamogeton and Myriophyllum) at this time is probably associated with local changes in the physical or chemical conditions of Sulphur Lake. For example, higher lake levels as a result of increased precipitation would have allowed aquatics to expand on the margins of Sulphur Lake. Pinus pollen increased shortly after the deposition of the White River Ash but has remained at low levels $(<5 \%)$. To the southeast, at Kettlehole Pond, Cwynar (1988) found Pinus contorta to be the dominant tree by $1900 \mathrm{yr}$ BP. Given that pine has not reached Sulphur Lake, the increase in Pinus pollen is presumably a function of transport linked to the dramatic increase in growing populations of pine to the south.

Johnson and Raup (1964), Workman (1978), and Morlan and Workman (1980) have suggested that extensive grassland communities occupied the southwest Yukon following deglaciation until roughly $3000 \mathrm{yr}$ BP. This largely speculative hypothesis was based on two elements. First, wood bison (Bison bison athabascae) fossils are present in early and middle Holocene sediments in the southwest Yukon. Second, early inhabitants (Little Arm and Gladstone cultural phases) were adapted to the hunting of grassland species, including muskox (Ovibos moschatus), caribou (Rangifer tarandus), and bison (Bison sp.) (MacNeish, 1964). However, the Sulphur Lake pollen diagram, as well as other nearby postglacial vegetation reconstructions (Rampton, 1971; Stuart et al., 1989), clearly indicate that a white spruce boreal forest has dominated the Shakwak Trench since at least $8000 \mathrm{yr}$ BP. Extensive grasslands were not present in the southwest Yukon in the early Holocene or at any time, as previous archaeological histories have proposed. In fact, at Sulphur Lake, grasses account for less than 5\% of the pollen sum for the period of record. As Stuart et al. (1989) and Keenan and Cwynar (1992) have indicated, regional archaeological reconstructions that suggest that early hunters and gatherers in the southern Yukon were adapted to widespread grassland environments (i.e., Johnson and Raup, 1964; Workman, 1978; Morlan and Workman, 1980) will have to be revised accordingly.

\section{SUMMARY}

At Sulphur Lake, a sparse shrub birch-herb tundra marked by the presence of Artemisia was present during the late-glacial and early Holocene. With a marked decrease in Artemisia and an increase in Betula, a birch shrub tundra prevailed between 11250 and $10250 \mathrm{yr} \mathrm{BP}$. Between 10250 and $8400 \mathrm{yr} \mathrm{BP}$, a poplar woodland with an understory of juniper scrub and dwarf birch was supported. Spruce invaded the region at $8400 \mathrm{yr}$ BP and the present white spruce boreal forest was established by about $8000 \mathrm{yr}$ BP. Alnus crispa increased at $6000 \mathrm{yr}$ BP at Sulphur Lake as it did throughout most of the Yukon, but Picea mariana did not increase.
There are problems with the Sulphur Lake basal radiocarbon date of $17370 \mathrm{yr}$ BP as well as Denton and Stuiver's (1966) $12500 \mathrm{yr}$ BP date from Jenny Lake. These difficulties and the lack of a reliable chronology for clearance of ice from the Shakwak Trench make it impossible to date the initial vegetation succession securely. If the regional deglaciation history is revised, the interpretation of the Sulphur Lake pollen diagram would need to be revisited.

\section{ACKNOWLEDGEMENTS}

Funding for this research was provided by a Natural Sciences and Engineering Research Council of Canada Science grant to K. Gajewski and by the Northern Scientific Training Program. Fieldwork was based at the Kluane Lake Research Station of the Arctic Institute of North America. Thanks to Peter Johnson for help in all aspects of this study and to M. Sawada for help with Figure 1. P. Leblanc, J. Pelland, and L. Levasseur generously assisted with fieldwork. Alayn Larouche at the Université de Montréal identified the plant macrofossils used in radiocarbon dating. R.J. Mott kindly reviewed the manuscript. Dr. T. Ager and two anonymous reviewers made suggestions that improved the quality of the manuscript.

\section{REFERENCES}

ANDERSON, P.M., and BRUBAKER, L.B. 1993. Holocene vegetation and climate histories of Alaska. In: Wright, H.E., Jr., Kutzbach, J.E., Webb T., III, Ruddiman, W.F., StreetPerrott, F.A., and Bartlein, P.J., eds. Global climates since the last glacial maximum. Minneapolis: University of Minnesota Press. 386-400.

BENNINGHOFF, W.S. 1962. Calculation of pollen and spores density in sediments by addition of exotic pollen in known quantities. Pollen et Spores 4:332-333.

BIRKS, H.J.B. 1977. Modern pollen rain and vegetation of St. Elias Mountains, Yukon Territory, Canada. Canadian Journal of Botany 55:2367-2382.

- 1980. Modern pollen assemblages and vegetational history of the moraines of the Klutlan Glacier and its surroundings, Yukon Territory, Canada. Quaternary Research 14:101-129.

CLAGUE, J.J., EVANS, S.G., RAMPTON, V.N., and WOODSWORTH, G.J. 1995. Improved age estimates for the White River and Bridge River tephras, western Canada. Canadian Journal of Earth Sciences 32:1172-1179.

CWYNAR, L.C. 1982. A late Quaternary vegetation history from Hanging Lake, northern Yukon. Ecological Monographs 52: 124.

1988. Late Quaternary vegetation history of Kettlehole Pond, southwestern Yukon. Canadian Journal of Forest Research 18:1270-1279.

CWYNAR, L.C., and SPEAR, R.W. 1991. Reversion of forest to tundra in the central Yukon. Ecology 72:202-212.

1995. Paleovegetation and paleoclimatic changes in the Yukon at 6 ka BP. Géographie Physique et Quaternaire 49: 2935. 
CWYNAR, L.C., BURDEN, E., and McANDREWS, J.C. 1979. An inexpensive method for concentrating pollen and spores from fine-grained sediments. Canadian Journal of Earth Sciences 16:1115-1120.

DAVIS, M.B., MOELLER, R.E., and FORD, J. 1984. Sediment focusing and pollen influx. In: Haworth, E.Y., and Lund, J.W.G., eds. Lake sediments and environmental history. Leicester, England: University of Leicester Press. 261-293.

DEAN, W.E. 1974. Determination of carbonate and organic matter in calcareous sediments and sedimentary rocks by loss on ignition: A comparison with other methods. Journal of Sedimentary Petrology 44:249-253.

DELCOURT, H.R., and DELCOURT, P.A. 1991. Quaternary ecology: A paleoecological perspective. London: Chapman and Hall.

DENTON, G.H., and KARLÉN, W. 1977. Holocene glacial and tree-line variations in the White River valley and Skolai Pass, Alaska and Yukon Territory. Quaternary Research 7:63-111.

DENTON, G.H., and STUIVER, M. 1966. Neoglacial chronology, northeastern St. Elias Mountains, Canada. American Journal of Science 264:577-599.

-1967. Late Pleistocene glacial stratigraphy and chronology, northeastern St. Elias Mountains. Geological Society of America Bulletin 78:485-510.

DOUGLAS, G.W. 1974. Montane zone vegetation of the Alsek River region, southwestern Yukon. Canadian Journal of Botany 52:2505-2532.

FAEGRI, K., and IVERSEN, J. 1989. Textbook of pollen analysis. 4th ed. Toronto: John Wiley \& Sons.

GLEW, J.R. 1988. A portable extruding device for close interval sectioning of unconsolidated core samples. Journal of Paleolimnology 1:235-239.

HANSEN, B.C.S., and ENGSTROM, D.R. 1985. A comparison of numerical and qualitative methods of separating pollen of black and white spruce. Canadian Journal of Botany 63: 2159-2163.

HOEFS, M., McTAGGART-COWAN, I., and KRAJINA, V.J. 1975. Phytosociological analysis and synthesis of Sheep Mountain, southwest Yukon Territory, Canada. Syesis 8:125228.

JOHNSON, F., and RAUP, H.M. 1964. Investigations in southwestern Yukon: Geobotanical and archaeological reconnaissance. Papers of the Peabody Museum of Archaeology and Ethnology. Cambridge: Harvard University Press. Paper 6:1-198.

KEENAN, T.J., and CWYNAR, L.C. 1992. Late Quaternary history of black spruce and grasslands in southwest Yukon Territory. Canadian Journal of Botany 70:1336-1345.

LACOURSE, T. 1998. Late Quaternary vegetation history of Sulphur Lake, southwest Yukon Territory, Canada. M.A. Thesis. University of Ottawa, Canada. 59 p.

LERBEKMO, J.F., WESTGATE, J.A., SMITH, D.G.W., and DENTON, G.W. 1975. New data on the character and history of the White River volcanic eruption, Alaska. In: Suggate, R.P., and Cresswell, M.M., eds. Quaternary studies. Royal Society of New Zealand Bulletin 13:203-209.
MACDONALD, G.M. 1984. Post-glacial plant migration and vegetation development in the western Canadian boreal forest. Ph.D. Thesis, University of Toronto, Canada. 261 p.

MacNEISH, R.S. 1964. Investigations in the southwest Yukon: Archaeological excavations, comparisons, and speculations. Papers of the Peabody Museum of Archaeology and Ethnology. Cambridge: Harvard University Press. Paper 6:199-488.

MORLAN, R.E., and WORKMAN, W.B. 1980. Prehistoric man in the southwest Yukon. In: Theberge, J.B., ed. Kluane: Pinnacle of the Yukon. Toronto: Doubleday. 97-107.

MOTT, R.J. 1978. Populus in late-Pleistocene pollen spectra. Canadian Journal of Botany 56:1021-1031.

MURRAY, D.F., and DOUGLAS, G.W. 1980. The green mantle. In: Theberge, J.B., ed. Kluane: Pinnacle of the Yukon. Toronto: Doubleday. 52-63.

NICKLING, W.G. 1978. Eolian sediment transport during dust storms: Slims River valley, Yukon Territory. Canadian Journal of Earth Sciences 15:1069-1084.

ORLÓCI, L., and STANEK, W. 1979. Vegetation survey of the Alaska Highway, Yukon Territory: Types and gradients. Vegetatio 41:1-56.

OSWALD, E.T., and SENYK, J.P. 1977. Ecoregions of Yukon Territory. Information Report BC-X-164. Victoria: Canadian Forestry Service, Pacific Forestry Research Centre. 115 p.

PARENT, S. 1988. Contribution à l'étude du paysage végétal d'une pessière, Baie Cultus, Lac Kluane (Yukon): Modèle de distribution spatiale des phytocénoses en fonction des facteurs abiotiques. M.Sc. Thesis. Université d'Ottawa. 118 p.

PRICE, L.W. 1971. Vegetation, microtopography, and depth of active layer on different exposures in subarctic alpine tundra. Ecology 52:638-647.

RAMPTON, V. 1971. Late Quaternary vegetational and climatic history of the Snag-Klutlan area, southwestern Yukon Territory, Canada. Geological Society of America Bulletin 82:959-978.

RICHARD, P. 1970. Atlas pollinique des arbres et de quelques arbustes indigènes du Québec 3. Angiospermes (Salicacées, Myricacées, Juglandacées, Corylacées, Fagacées, Ulmacées). Naturaliste Canadien 97:97-161.

RITCHIE, J.C. 1984. The past and present vegetation of the far northwest of Canada. Toronto: University of Toronto Press.

1987. Postglacial vegetation of Canada. Cambridge: Cambridge University Press.

RITCHIE, J.C., and MACDONALD, G.M. 1986. The patterns of post-glacial spread of white spruce. Journal of Biogeography 13:527-540.

ROWE, J.S. 1972. Forest regions of Canada. Publication No. 1300. Otttawa: Canadian Forestry Service. 177 p.

STUART, G.S.L., HELMER, J.W., and HILLS, L.V. 1989. The Holocene paleoecology of Jenny Lake area, southwest Yukon, and its implications for prehistory. Arctic 42:347-353.

THOMPSON, R., BLOEMENDAL, J., DEARING, J.A., OLDFIELD, F., RUMMERY, T.A., STOBER, J.C., and TURNER, G.M. 1980. Environmental applications of magnetic measurements. Science 207:481-486.

WANG, X.-C. 1989. Post-glacial vegetation history of the Aishihik Basin and its vicinity, southwest Yukon Territory: A palynological perspective. Ph.D. Thesis. University of Ottawa. 544 p. 
WANG, X.-C., and GEURTS, M.-A. 1991a. Late Quaternary pollen records and vegetation history of the southwest Yukon Territory: A review. Géographie Physique et Quaternaire 45: 175-193.

1991b. Post-glacial vegetation history of the Ittlemit Lake basin, southwest Yukon Territory. Arctic 44:23-30.
WORKMAN, W.B. 1978. Prehistory of the Aishihik-Kluane area, southwest Yukon Territory. Archaeological Survey of Canada, Mercury Series Paper 74. Ottawa: National Museum of Man. WRIGHT, H.E., Jr. 1967. A square-rod piston sampler for lake sediments. Journal of Sedimentary Petrology 37:957-976. 